the phenomenon usually attributed to the interference of the two rays which, distinct at incidence, coincide on emergence. However this may be, the fact can have nothing to do with the present question. It is impossible, when the most refined spectroscopic observation hardly gives us one octave, that the rainbow should disclose three or four.

Hyères, Jan. 25

\section{J. MONRO}

\section{Flight of Birds}

WITH reference to an abstract of a paper by Mr. Southwell on the flight of birds, which appeared in your paper a few weeks back, I venture to make the following note and inquiry.

A late brother of mine who had been round the Cape, and had frequently observed carefully the flight of the albatioss, told me that though he had watched individual birds on several occasions for many minutes together, he had seldom or never seen any of them flap their wings. Has this fact been observed by other persons, and if it be authenticated, has Mr. Southwell any explanation to offer?

J. H.

\section{Turdus Whitei}

Ir may interest some of your ornithological readers to know that a specimen of White's Thrush, Turdus Whitei, was killed near here on the 7 th inst. It was shot by Mr. J. Beadon, of Gotten House, and presented by him to $\mathrm{Mr}$. Cecil Smith, of Lydeard House, for his collection. This is, I believe, the fourth occurrence of this bird in Britain; it is, I think, even less known on the Continent.

Museum, Taunton, Jan. I5

\section{THE SARS FUND}

WE are glad to find that the appeal made in our pages by Mr. Gwyn Jeffreys, on behalf of the family of the late Professor Sars of Christiania, is being warmly seconded in Paris by M. Alglave, the Editor of the Revue des Cours Scientifiques. In the last number of the Rezue Mr. Gwyn Jeffreys' article is reprinted in extenso, and an announcement made that subscriptions to the Sars Fund will be received at the office of that journal. But $M$. Alglave has not waited for the publication of his notice before beginning his good work; he has already collected the sum of 2,026 francs $(81 \%)$, and publishes with the notice a first subscription-list containing the names of many of the most eminent naturalists in France. We have now the pleasure of giving in our advertising columns a list of the contributions already promised to Mr. Gwyn Jeffreys. Sars belonged to the best type of scientific men, the genuine lover of science, contented to work in obscurity without thought of honours or reward. His family have a special claim to help, inasmuch as the distress in which they are left is not due to neglect or extravagance on the part of the lamented Professor, but is solely attributable to his having devoted himself to studies, which, notwithstanding the most self-denying labours, did not enable him to make any provision for the future. Those of our readers who have visited Norway, who know the genuine unworldly ways of the Norwegians, and who have enjoyed the enthusiastic welcome so readily given to the English, have now a graceful opportunity of reciprocating the kindly feeling shown them by the countrymen of Sars.

\section{NOTES}

LORD DE GREY will tomorrow receive the Council of the British Association, as a deputation to unge upon her Majesty's Government the desirableness of a Royal Commission being issued to inquire into the present state of Science in this country.

THE Royal Society and the Royal Astronomical Society have both appointed committees of council, to report upon the steps which it may be desirable to take in connection with the total eclipse of the sun, visible in Algeria, Spain, and Sicily, in December next.
IT is proposed to celebrate the fiftieth anniversary of the Royal Astronomical Society by a dinner on the day of the annual meeting, February II.

THE lectures annually delivered in the theatre of the Royal College of Surgeons were commenced yesterday by Professor Erasmus Wilson, F.R.S., who will deliver six lectures on Dermatology. To illustrate that of yesterday, there were a large number of exquisitely-prepared models, duplicates of those prepared for the Hôpital St. Louis, Paris. Professor Wilson's course will be followed by Professor Flower, F.R.S., Conservator of the Museum, who will deliver 18 lectures introductory to the study of the anatomy of the class mammalia.

THERE is a terrible rumour to which we are compelled to refer, though it has reached us in a-let us hope-doubtful way. The news is, that Livingstone has been murdered and burnt ninety days' journey from the Congo.

THE Zoölogical Society of London have now in the press a memoir by Dr. O. Fiusch, of Bremen, one of their corresponding members, upon the birds collected by $\mathrm{Mr}$. William Jesse during the recent Abyssinian expedition. This memoir, which was read before the society at one of their meetings last year, will appear in their quarto Transactions, and will be illustrated by coloured figures of the new or little-known species. It will be in the recollection of some of our readers that $\mathrm{Mr}$. Jesse was selected by the Zoölogical Society, at the request of the Treasury, to accompany the Abyssinian expedition as zoölogist, and that the society undertook the task of bringing the results of his investigations before the public. Dr. W. Peters, of Berlin, has undertaken to prepare a memoir upon some of the rarer mammalia obtained by Mr. Jesse during the expedition, which will likewise appear in the Transactions. Mr. W. T. Blanford, who was sent out by the Indian Government as geologist to the expedition, is preparing a separate work upon his discoyeries, which will be published by Messrs. Macmillan.

AT its last meeting (January 24), the Academy of Sciences elected a new correspondent for the Physical section in the place of the late Professor Forbes. M. Kirchhoff, who was the successful candidate, obtained forty votes; IMIr, Lloyd and Sir William Thomson received one vote each.-A committee of the three sections of Astronomy, Geometry, and Navigation selected the following candidates for the vacancy in the Bureaz des Longitudes:-1. M. de la Roche Poncié ; 2. M. Gaussin.

IT is no secret that the present régime at the Observatory of Paris has been rather more autocratic than could be patiently endured, even in a country subjected to eighteen years of personal government. Matters have at length reached a crisis, and the Minister of Public Instruction is placed in the awkward position of having to dismiss from the public service one of the most eminent of modern astronomers, or accept the resignation of the whole of the rest of the staff of the Observatory.

THE chair of Chemistry at the University of Tuibingen has been offered to Prof. Fittig.

WE regret to have to announce the death! of a naturalist of great promise, Dr: Wilhelm Keferstein, Ordinary Professor" of Zoölogy and Comparative Anatomy in the University of Göttingen. He died on the 25 th ult, at the early age of 37.

THOSE of our readers who are acquainted with the grand series of ethnographical photographs contained in the four volumes already published of the work entitled the "People of India," will be glad to hear that four more instalments completing the volume are now in progress. The publishers are Messrs. W. H. Allen and Co., of Waterloo Place.

M. Schafarik, Professor of Chemistry in the Polytechnic Institute of Bohemia, writing on the 15 th ult. to the Bohemian newspaper Politik, announces the discovery of a diamond in a 